\title{
軟弱地盤における建築構造物の即時沈下および 圧密沈下の三次元有限要素法解析
}

$\begin{array}{lllll}\text { 正会員 } & \text { 土 } & \text { 屋 } & & \text { 勉* } \\ \text { 正会員 } & \text { 大 } & \text { 築 } & \text { 和 } & \text { 夫** } \\ \text { 正会員 } & \text { 小 } & \text { 幡 } & & \text { 守*** }\end{array}$

\section{§1. まえがき}

軟弱地盤地域においては，建築構造物の基礎を深部の 良質な砂れき層に杭支持させる工法が一般的に行われて きた。ところが，地盤沈下による過大なネガティブフリ クションが杭体に作用する可能性があり，これに抵抗す るには杭本数を増加させたり特殊な杭を用いる必要が生 ずる。そのため，最近では支持杭を用いずに，摩擦杭の 利用や表層地盤を改良して直接基礎を採用するといった 試みもいくつかみられるようになった。これらの工法を 用いる場合は，事前に構造物の沈下量をできるだけ正確 に予測し，その結果に基づいて構造物の不同沈下に対し て配慮する必要がある。

建築構造物の不同沈下の計算に際しては，上部構造之 地盤の相互作用を考慮する必要があり，この計算法に関 する既往の研究として次のようなものが挙げられる。横 尾・山肩 ${ }^{11} は$, Terzaghi の一次元圧密理論を基にして地 盤内応力の変化を考慮した圧密式を誘導した。さらに, 上部構造のせん断剛性を考慮して, 各基礎位置について 沈下に関する連立微分方程式を作成し，地下粘土層の圧 密に伴う建物の不同沈下過程を計算した。大崎 ${ }^{21}$ は, 横 尾・山肩" ${ }^{1}$ 同様の変動圧を受ける圧密式や弾性地盤と しての地盤係数理論にしたがう地盤条件を基礎位置の境 界条件として与えて, 上部構造のクリープを考虑しなが ら不同沈下による架構応力問題を解く理論式を導いた。 松浦 ${ }^{3}$ は，これらの計算法が煩雑に過ぎる憾みがあると して, 粘土層に Kelvin の粘弾性モデルを用い, 上部構 造の応力伝達マトリックスにD法を用いる等して実用を 目的とした近似理論を示した。中田・山肩 ${ }^{4}$ は, 先の不 同沈下理論" の考え方を㹡張して, 杭基礎を有する構造 物にも適用できるようにした。松浦・山本 ${ }^{5}$ は, 粘土層 にBiot の圧密理論を適用するとともに, Boussinesq の 解を利用して上部砂層の変形も考慮しながら, 独立基礎 およびべ夕基礎を有する構造物の沈下解析を行った。そ

* 室蘭工業大学 講師・工修

** 室蘭工業大学 教授・工博

*** 北海道大学 教授. 工博

(昭和 60 年 7 月 5 日原稿受理)
の他に, 不同沈下の進行過程の計算方法としては, 赤 井・小沢 ${ }^{6)}$, P. Brown ${ }^{7)}$, S. Chamecki ${ }^{8}$ 等の研究があ り，終局時の不同沈下に限定したものについては，S. Chamecki $^{(9)}$ や芳賀 ${ }^{10)}$ を始めとする多数の報告 ${ }^{(1)}$-14) がみ られる。

しかし，これらの計算方法を用いて建物の不同沈下過 程をシミュレートするには，次のような諸点において必 ずしも十分ではないように思われる。

(1) 本来三次元的な挙動を示す粘性土地盤を一次元圧 密モデルとしているため, 非排水時におけるせん断変形 や水平方向の圧密変形が解析されない。したがって，粘 土層が地中のかなり深い位置に在り，かつその層厚の薄 いような場合を除いて，解析結果は大きな誤差を含む可 能性があること。

(2) 地中の応力伝播を半無限弾性地盤における Boussinesq 式に基づいて算定しているので, 変形係数の著 しく異なる砂層と粘土層が交互に続くような多首地盤に おいては，地盤の異質性の影響による誤差が大きくなる 可能性があること。

(3) 直接基礎や支持杭基礎を有する構造物を対象とし ており，摩擦杭基礎への応用が難しいこと。

そこで本報では，上記の諸点に配虑を加えた有限要素 法による解析手法を提示するとともに，予備計算を行っ てその妥当性と適用範囲について検討を行った。なお, 本報で有限要素法を用いたのは, 地盤および杭の材料特 性や両者間の境界条件の設定が容易なためである。また， 本報の解析法で特に配慮したのは以下の点である。

(1) Christian ${ }^{15)}$ が三角形要素に適用したと同様の有 効応力概念を新たに三次元の直方体要素に導入して, 粘 性土の非排水せん断変形（即時沈下）と圧密変形（圧密 沈下）の両者を解析に取り入れるようにしたこと。

(2) 砂質土は時間依存性の無い弾性体として粘性土と 連成させて変形解析を行い, 応力伝播に関する地盤の異 質性が自動的に考慮されるようにしたこと。ただし，本 報の予備計算においては地表面から支持層まで均質な粘 性土が連続しているものと仮定した。

(3) 杭と地盤の境界に弾塑性せん断バネを設け，摩擦 
杭の解析に杭周面のすべりを考慮したこと。

\section{§2. 解析法}

\section{1 地盤(要素}

\section{(1) 粘汢}

変位については 8 節点直方体要素を用いて計算し, 過 剩間隙水圧については, 分割数が多くなると後述する差 分式の安定性が非常に悪くなる傾向が予備計算でみられ たので，できるだけ節点を少なくするために要素中央位 置（図一1の節点(9)）で計算することにした。粘土は飽 和されており, 粘土骨格は等方弾性体, 粘土中の流体水 は非粘性・非圧縮の完全流体と仮定して, 以下に単位要 素マトリックスを誘導する。

全応力を $\{\sigma\}$, 有効応力を $\left\{\sigma^{\prime}\right\}$, 過剩間隙水圧を $\left\{P_{w}\right\}$ とすると,

$$
\begin{aligned}
& \left\{\sigma \mid=\left\{\sigma^{\prime}\right\}+\left\{P_{w}\right\}\right. \\
& \text { ただし， }\{\sigma\}=\left\{\begin{array}{llllll}
\sigma_{x} & \sigma_{y} & \sigma_{z} & \tau_{x y} & \tau_{y z} & \tau_{z x}
\end{array}\right\}^{T} \\
& \left\{\sigma^{\prime}\right\}=\left\{\begin{array}{lllllll}
\sigma_{x}^{\prime} & \sigma_{y}^{\prime} & \sigma_{z}^{\prime} & \tau_{x y} & \tau_{y z} & \tau_{z x}
\end{array}\right\}^{T} \\
& \left\{P_{w}\right\}=\left\{\begin{array}{llllll}
P_{w} & P_{w} & P_{w} & 0 & 0 & 0
\end{array}\right\}^{T}
\end{aligned}
$$

ここで (1) 式に仮想仕事の原理を適用して, 変位関 数 $[N]$ ，ひずみマトリックス $[B]$ および弾性マトリック ス $[D]$ を代入して整理すると, 次のような節点力 $\{F\} の$ つり合い式が得られる。

$$
\begin{aligned}
\{F\} & =\int_{V}[B]^{T} \cdot[D] \cdot[B] d V \cdot\{\delta\}+\int_{V}[B]^{T} \cdot\left\{P_{w}\right\} d V \\
& =\left[K_{E}\right] \cdot\{\delta\}+\left[K_{p}\right] \cdot P_{w} \cdots \ldots \ldots \ldots \ldots \ldots \ldots \ldots \ldots .(2)
\end{aligned}
$$

ただし， $\left\{F \mid=\left\{\left.\begin{array}{llllllll}X_{1} & X_{2} \cdots X_{8} & Y_{1} & Y_{2} \cdots Y_{8} & Z_{1} & Z_{2} \cdots Z_{8}\end{array}\right|^{T}\right.\right.$

$X_{t}, Y_{b}, Z_{t}: i$ 節点の $x, y, z$ 方向節点力

$\left[K_{\mathrm{E}}\right]$ : 有効応力の剛性マトリックス $\{\delta\}=\left\{\left.\begin{array}{llllllll}u_{1} & u_{2} \cdots u_{8} & v_{1} & v_{2} \cdots & v_{8} & w_{1} & w_{2} \cdots w_{8}\end{array}\right|^{\top}\right.$ $u_{i}, v_{i}, w_{i}: i$ 節点の $x, y, z$ 方向変位

$\left[K_{\boldsymbol{p}}\right]$ : 過剩間隙水圧マトリックス

$P_{w}:$ 要素中央位置の過剩間隙水圧

$$
\begin{aligned}
& {[B]=\left[\begin{array}{ccc}
B_{x} & 0 & 0 \\
0 & B_{y} & 0 \\
0 & 0 & B_{z} \\
B_{y} & B_{x} & 0 \\
0 & B_{z} & B_{y} \\
B_{z} & 0 & B_{x}
\end{array}\right] \ldots \ldots \ldots \ldots \ldots .} \\
& {\left[B_{x}\right]=\left[\begin{array}{llll}
\frac{\partial N_{1}}{\partial x} & \frac{\partial N_{2}}{\partial x} & \cdots & \frac{\partial N_{s}}{\partial x}
\end{array}\right]} \\
& {\left[B_{y}\right]=\left[\begin{array}{llll}
\frac{\partial N_{1}}{\partial y} & \frac{\partial N_{2}}{\partial y} & \cdots & \frac{\partial N_{s}}{\partial y}
\end{array}\right]} \\
& {\left[B_{z}\right]=\left[\begin{array}{llll}
\frac{\partial N_{1}}{\partial z} & \frac{\partial N_{2}}{\partial z} & \cdots & \frac{\partial N_{s}}{\partial z}
\end{array}\right]} \\
& N_{t}=\left(1+\xi \cdot \xi_{t}\right) \cdot\left(1+\eta \cdot \eta_{t}\right) \cdot\left(1+\zeta \cdot \zeta_{t}\right) / 8 \\
& \xi=x / a, \eta=y / b, \quad \zeta=z / c \\
& \xi_{t}=x_{t} / a, \eta_{t}=y_{t} / b, \quad \zeta_{t}=z_{t} / c \\
& {[D]=\frac{E_{s}^{\prime}}{\left(1-\nu_{s}^{\prime}\right) \cdot\left(1-2 \nu_{s}^{\prime}\right)} \cdot}
\end{aligned}
$$

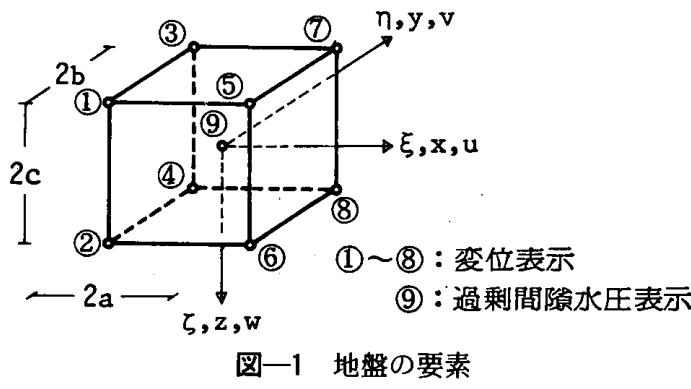

$\left[\begin{array}{cccccc}1-\nu_{s}^{\prime} & & & & & \\ \nu_{s}^{\prime} & 1-\nu_{s}^{\prime} & & & s y m . & \\ \nu_{s}^{\prime} & \nu_{s}^{\prime} & 1-\nu_{s}^{\prime} & & & \\ 0 & 0 & 0 & \frac{1-2 \nu_{s}^{\prime}}{2} & & \\ 0 & 0 & 0 & 0 & \frac{1-2 \nu_{s}^{\prime}}{2} & \\ 0 & 0 & 0 & 0 & 0 & \frac{1-2 \nu_{s}^{\prime}}{2}\end{array}\right]$

$E_{s}^{\prime}:$ 粘土骨格の弾性係数

$\nu_{s}^{\prime}:$ 粘土骨格のポアンン比

ここで流量に関する連続式を導入する。要素の体積ひ ずみを $\varepsilon_{v}$ とすると，

$$
\begin{aligned}
\varepsilon_{v} & =\varepsilon_{x}+\varepsilon_{y}+\varepsilon_{z} \\
& =\left[\begin{array}{lll}
B_{x} & B_{y} & B_{z}
\end{array}\right] \cdot\{\delta\}
\end{aligned}
$$

（5）式の両辺に要素の体積 $8 a b c$ を乗ずると,

$$
8 a b c \cdot \varepsilon_{v}=\left[K_{p}\right]^{T} \cdot|\delta| \cdot
$$

(2) 式と（6) 式を連立させると, 次の単位要素又 トリックスが得られる。

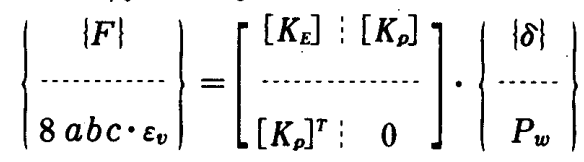

非排水状態においては，（7) 式に $\varepsilon_{v}=0$ を代入する ことによって非排水時の節点変位と初期過剩間隙水圧を 算定することができる。

次に，排水状態の解析法について述べる。先す， $\varepsilon_{v}$ を算定するのに，（8）式の Biot $の$ 多次元圧密方程式 ${ }^{16)}$ を利用する。

$$
\frac{\partial \varepsilon_{v}}{\partial t}=\frac{1}{r_{w}}\left(k_{x} \cdot \frac{\partial^{2} P_{w}}{\partial x^{2}}+k_{y} \cdot \frac{\partial^{2} P_{w}}{\partial y^{2}}+k_{z} \cdot \frac{\partial^{2} P_{w}}{\partial z^{2}}\right)
$$

\section{ただし, $r_{w}:$ 水の単位体積重量}

$$
k_{x}, k_{y}, k_{z}: x, y, z \text { 方向の透水係数 }
$$

圧密方程式の数値解法としては差分法や有限要素法が あるが，主として簡便であるとの理由から一般に差分法 を利用することが多い。本報では，赤井・田村17等が二 次元平面ひずみ問題の解析に利用したBiot の圧密方程 式を差分化する方法を, 三次元問題に拡張して用いるこ とにする。すなわち，図一2 のように格子を設けて（8） 式を差分表示すると, 次のように微小時間 $\Delta t$ 後の体積 


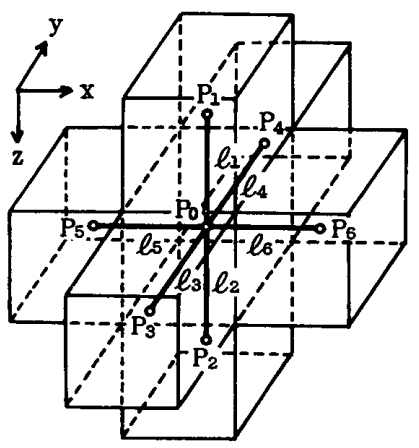

$\mathrm{P}_{0}$ : 求めようとする 直方体要素内の 過剩間償水印

$\mathrm{P}_{1} \sim \mathrm{P}_{6}$ ：隣接する直方体 要素内の過剩間 螅水殴

$\ell_{1} \sim \ell_{6}:$ 中央の要素と隣 挼する要素との 図心距離

図一2 差分の格子

ひずみが容易に得られる。

$$
\begin{aligned}
\varepsilon_{v(t+\Delta t)}= & \varepsilon_{v(t)}+\Delta t \cdot \frac{2}{r_{w}}\left\{\frac{l_{5}\left(P_{6}-P_{0}\right)-l_{6}\left(P_{0}-P_{5}\right)}{l_{5} \cdot l_{6}\left(l_{5}+l_{6}\right)} \cdot k_{x}\right. \\
& +\frac{l_{3}\left(P_{4}-P_{0}\right)-l_{4}\left(P_{0}-P_{3}\right)}{l_{3} \cdot l_{4}\left(l_{3}+l_{4}\right)} \cdot k_{y} \\
& \left.+\frac{l_{1}\left(P_{2}-P_{0}\right)-l_{2}\left(P_{0}-P_{1}\right)}{l_{1} \cdot l_{2}\left(l_{1}+l_{2}\right)} \cdot k_{z}\right\} \cdots \cdots(9)
\end{aligned}
$$

ゆえに，排水状態においては（9）式で求めた $\varepsilon_{v(t+\Delta t)}$ を先の $(7)$ 式に代入することで, $\Delta t$ 時間後の節点変 位と過剩間隙水圧を逐次計算によって求めることができ る。

\section{（2）砂質土}

砂質土は時間依存性のない線型弾性体と仮定し, それ を図一1の要素から節点(9)を取り除いた直方体要素を用 いて表す。

\section{2 上部構造および基礎の要素}

単位要素を図一 3 に示す。基礎スラブには面内力およ び面外力を考慮する非適合長方形要素を, 柱・はりおよ び杭には軸力，2つの主軸面内における曲げおよびねじ りを考慮するはり要素を用いた。これらの要素はいずれ も応力および時間に依存しない線型弾性体であると仮定 して材料常数を定めた。なお, 図一1の地盤の要素の節 点間変形は線型となるのに対して, 図一 3 の上部構造お

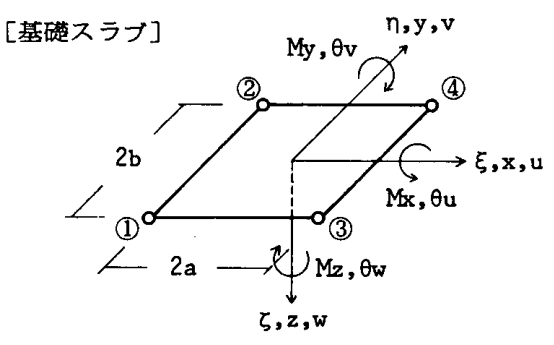

[柱,梁, 杭]

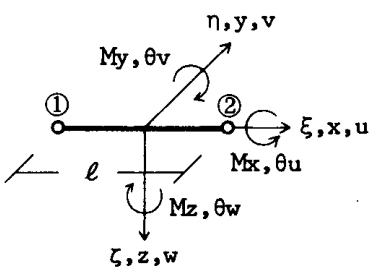

图一3上部構造および基礎の要素

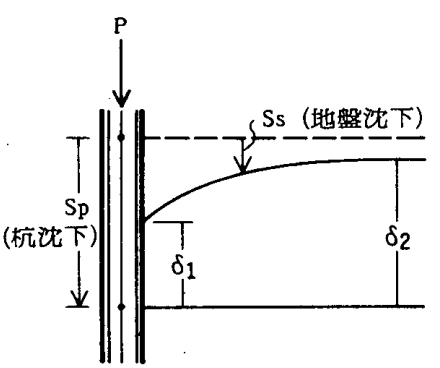

図一4杭と地盤の相対変位 $(\delta)$
よび基礎のそれは非線型となる。したがって，基礎スラ ブ，基礎ばりおよび杭と地盤の境界では適合条件が成立 しなくなるが，この影響については 33 で考察を行う。

2.3 杭周面と地盤の境界の要素

杭周面と地盤の間ではすべりが発生するものとして， 両者をせん断バネで結合した。このバネ係数 $k_{s}$ は，杭 周面すべり量 $w_{s l}$ の值によって次のように表されるもの とした。

$$
\left.\begin{array}{ll}
w_{s l} \leq w_{s l s} \text { の時 } & k_{s}=\alpha \cdot \sigma_{v}^{\prime} / w_{s i s} \\
w_{s l} \geq w_{s l s} \text { の時 } & k_{s}=0
\end{array}\right\}
$$

ただし， $w_{s l s}$ : 杭周面摩擦力 $f$ が最大值に達する時 のすべり量

$\alpha$ : 杭周面最大摩擦力 $f_{\max }$ と杭周面地盤の鉛 直方向有効土被り王 $\sigma_{v}^{\prime}$ の比例係数

(10) 式の $\alpha$ および $w_{s l s}$ の值は，既往の実大杭の鉛直 載荷試験やネガティブフリクションの長期測定によって 得られたもので，次のような見掛けのすべり量に基づい て定めたものである。すなわち，図一4 は杭之地盤の境 界周辺の変位分布の一般的傾向を示したものであるが, 杭周面のすべり量 $\delta_{1}$ を直接測定することは極めて難し いため，既往の実測值は杭周面よりある程度離れた位置 の地盤と杭の変位差 $\delta_{2}$ (見掛けのすべり量) となる。

図一5は，このようにして得られた摩擦力〜すべり量 関係を示したものである。 $\sigma_{v}^{\prime}$ が一定の場合，両者の関 係は図中の(1)のようにバイリニアとなる。しかし，一 般には非排水状態における建物荷重の増加および排水状 態における圧密の進行とともに $\sigma_{v}^{\prime}$ が増加するので, す ベり量が大きくなるにつれて $k_{s}$ も大きくなる。このた め, 両者の関係は図中の四のように凹型の変化を示し て最大値に達することになる。

上述の非線型性を計算に採り入れるにあたって，本報 では全体の剛性マトリックスを作り変える代わりに等価 節点力を加えて計算する応力伝達法を用いた。

\section{§3. 予備計算}

3.1 要素境界面の非適合性について

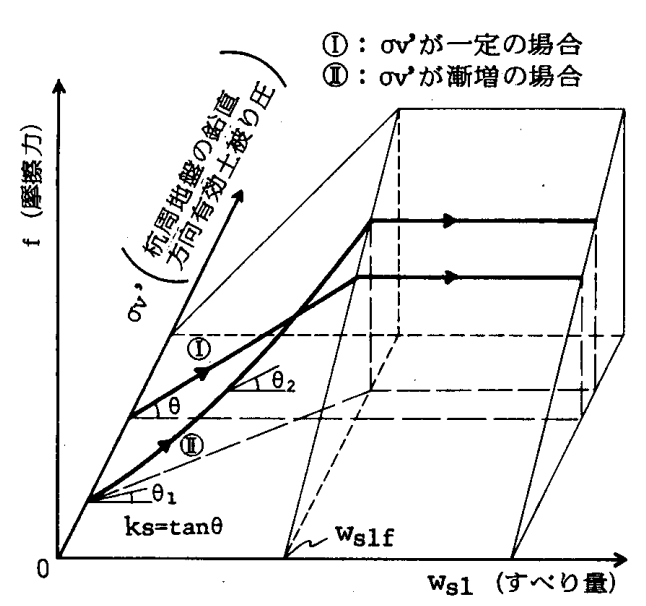

図一5 $f \sim w_{s l} \sim \sigma_{v}^{\prime}$ の関係 


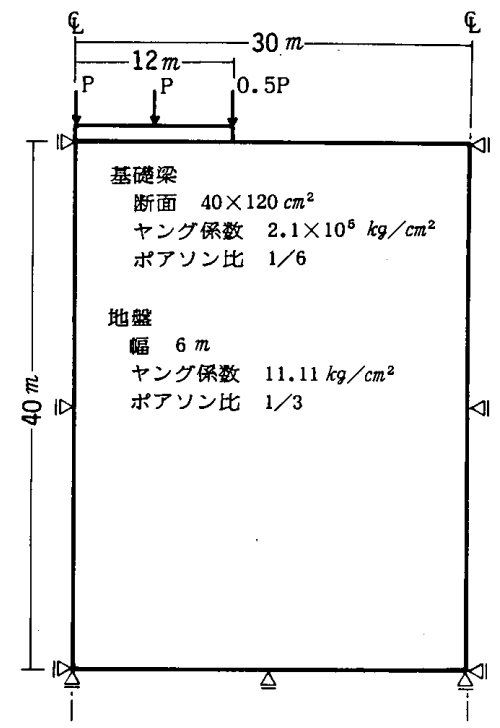

図一6 解析モデルの諸元

基礎に用いた図一3 の要素と地盤に用いた図一1の要 素を連成すると，両者の節点を除く境界では適合条件を 満たさなくなる。この影響を明らかにするために，弾性 地盤上に載る基礎ばりを例にとって，適合条件を満たす モデルと満たさないモデルの両者を二次元的に解析して 比較検討することにする。

解析の対象は，図一6に示すように深さ $40 \mathrm{~m}$ の地盤 上に 4 スパンで長さ $24 \mathrm{~m}$ の基礎ばりが載っている場合 である。この基礎ばりが奥行方向および水平方向にそれ ぞれ等間隔に配置されているものと仮定して，地盤につ いては平面ひずみの長方形要素で分割するとともに，水 平方向には図のような対称条件を設定した。なお，計算 は終局状態について実施した。

表一1に解析したモ゙デルを示す。RIP は基礎ばりを平 面応力の長方形要素で分割したものであり，地盤との境 界で適合条件を満たす。B1〜B6は基礎ばりにはり要 素を用いたモデルであり，地盤との境界では非適合とな る。なお，地盤の鉛直方向分割はすべて 8 等分割であり， 周辺地盤の水平方向分割は各モデルの基礎ばりの分割幅 に等しくした。

解析結果として, 基礎ばりの沈下と曲げモーメント分 布を図一7に示した。B1〜B6の沈下は，RIPに比べ て基礎ばりの中央部で大きく端部で小さくなっているも ののほぼ近似している。また，基礎ばりの分割を細かく していくにつれて，はり要素を用いた場合の基礎ばりの 中央部と端部の相対沈下は小さくなるのに対して，長方 形要素を用いた場合のそれは逆に大きくなって，両者の 值が一致してくる傾向がみられた。次に，基礎ばりの曲 げモーメントについて比較する。B1〜B 6 の各分割位 置における值は RIP の値（基礎ばり断面の水平方向節 点力をもとに主軸位置について計算したもの）に良く近 似しており，分割数による影響もほとんどみられない。
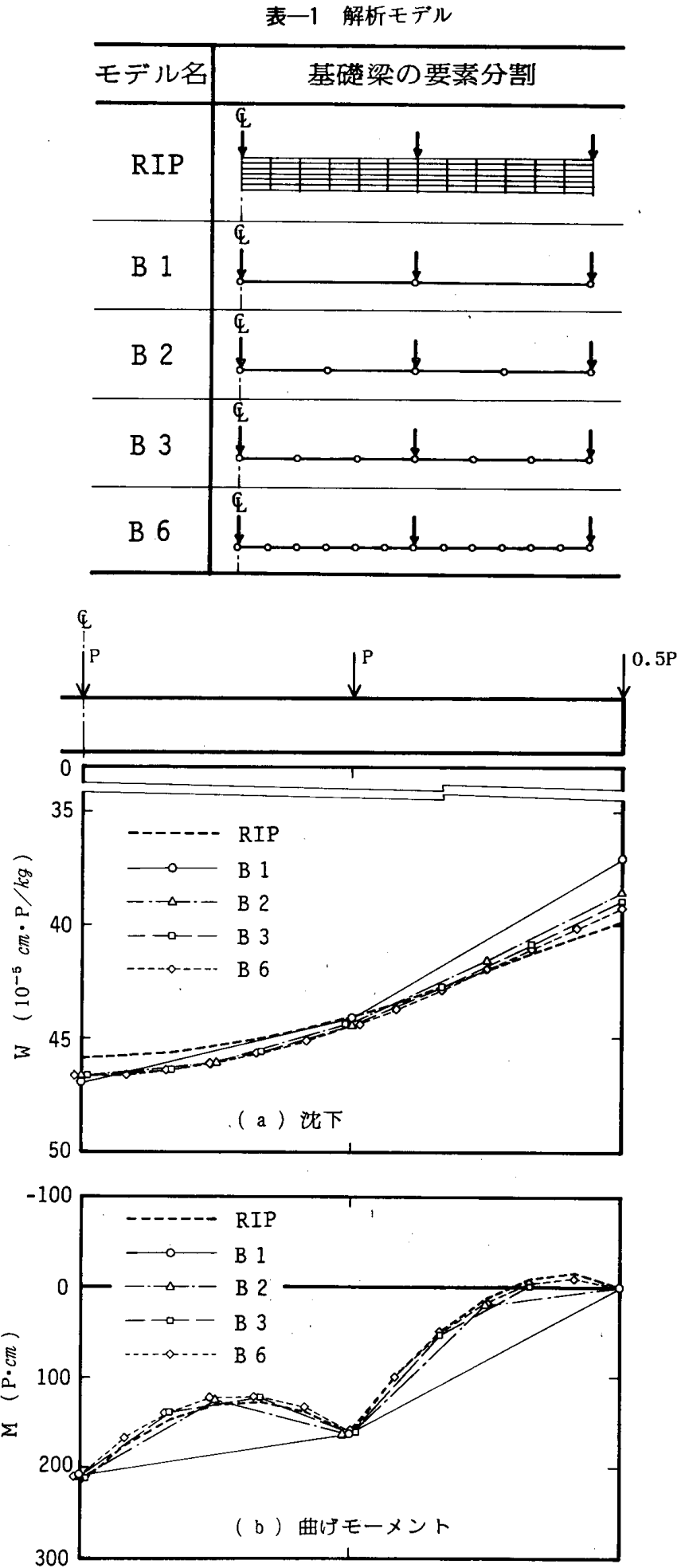

図一7基礎ばりの沈下および曲げモーメント分布

したがって，基礎ばりの支点間の応力分布を詳しく知る 必要がないなら，B1のような分割の粗いモデルを用い ても全体の傾向を表し得るものと思われる。

なお，杭と地盤の境界についても上記と同様の検討を 行ったところ，非適合条件となることによる影響はさら に小さくなることが分った。また，適合条件を満たすモ デルに比べて極めて少ない分割数で解析できるという計 算上極めて大きな利点がある。以上のことから，本研究 
では図一 3 の要素と図一1の要素を組み合わせた解析法 を用いて論を進めることにする。

\section{2 分割方式の影響について}

有限要素法を用いた解析結果が要素分割方式の影響を 受けることは良く知られている。そこで，鈶直方向およ び水平方向の地盤分割数をそれぞれ変えて解析した結果 について比較検討する。

解析の対象は, 正規圧密状態にある沖積粘性土が地表 面から深さ $40 \mathrm{~m}$ まで一様に分布する軟弱な地盤上に, $24 \mathrm{~m} \times 24 \mathrm{~m}$ の正方形平面をもつ建物が直接基礎および 摩擦杭基礎を介して支持される場合である。この建物が 中心間隔 $60 \mathrm{~m}$ で無限に配置されているものと仮定し て，水平方向については図一8に示すような対称条件を 設定した。また，粘土層とその下部の砂れき層との境界 は粗面であって，その境界での水平方向変位は生じない ものとした。建物は 3 階建てで瞬時に完成するものと仮 定して, 上部構造および基礎の剛性を考慮するとともに, 各柱の支配面積に応じて $5 \mathrm{t} / \mathrm{m}^{2}$ に相当する荷重を 1 階 柱脚に作用させた。摩擦杭基礎を有するモデルでは，l $=25 \mathrm{~m}$ の杭を建物の中央部, 辺部, 隅角部にそれぞれ 4 本, 2 本, 1 本づつ配した。これらの杭については群 杭となることの相互作用を無視して，単杭と同様の挙動 を示すものと仮定した。なお，図一8のモデルについて 杭の曲げ剛性を考慮した場合とそれを無視した場合につ いて解析したところ，後述の表一6に示すように両者の 沈下性状はほぼ近似していた。そこで，より簡単化を図 り，ここでは杭の剛性として軸力のみを考慮して解析す ることにした。また，杭と地盤の境界におけるせん断バ ネを算定する時の常数は，実大杭によるネガティブフリ クションの実測値に関する文献 ${ }^{18)}$ を参考にして,$w_{s l}=$ $3 \mathrm{~cm}$ および $\alpha=0.3$ と仮定した。表一 2 に示した地盤の ヤング係数, ポアソン比および透水係数は，仮定した体 積圧縮係数 $m_{v}$ と圧密係数 $C_{v}$ に等価になるように設定 した。ここで, $m_{v}=6 \times 10^{-2} \mathrm{~cm}^{2} / \mathrm{kg}$ は沖積粘性土の代 表値として使用されることの多いW.A. Skemptonの 提案值 ${ }^{16)}$ であり， $C_{v}=2 \times 10^{3} \mathrm{~cm}^{2} /$ day は文献 ${ }^{19}$ に収集さ れている值を参考にして仮定したものである。また，粘 性土の透水係数は一般に水平方向が鉛直方向よりも大き いとされているが，現状では透水性の異方性に関する データが不足しており代表值を設定し難いと思われたこ とや，本論文の結果と既往の圧密理論解との比較が容易 になることを考慮して，ここでは両方向の值が等しいも のと仮定した。

以上の条件のもとで，図一-8のように要素分割した場 合を基本モデルとして, 表一 3 と表一 4 の分割方式を組 み合わせた表一 5 のモデルについて解析を行った。モデ ル名の RP およびRS の記号は，それぞれ直接基礎およ び摩擦杭基礎で支持される構造物であることを示す。な

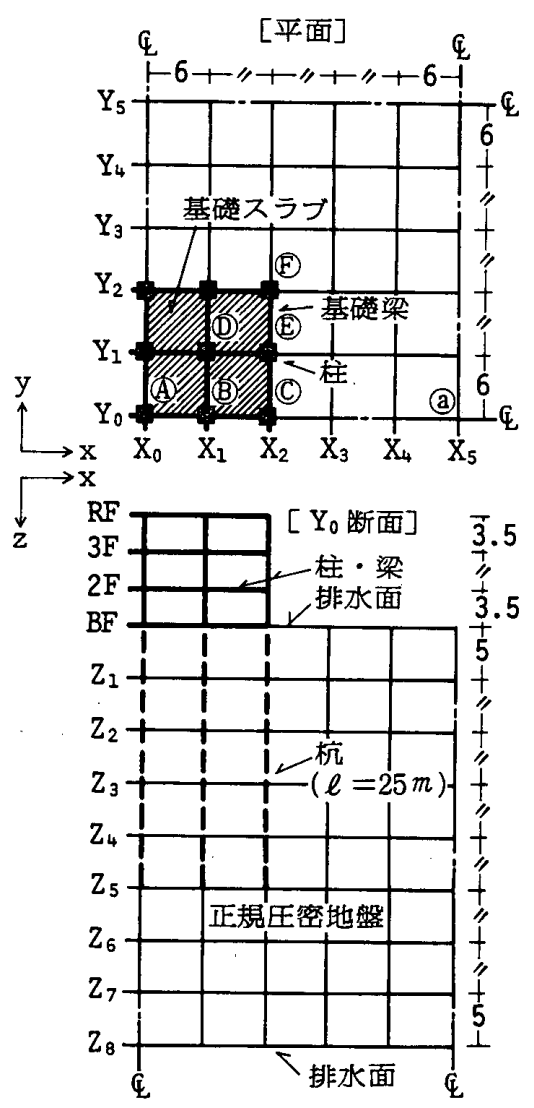

図一8 基本モデル (RS-E, RP-E) の要素分割（単位：m)

表一2 解析モデルの諸元

\begin{tabular}{|c|c|c|}
\hline $\begin{array}{l}\text { 上 } \\
\text { 部 } \\
\text { 構 } \\
\text { 造 }\end{array}$ & $\begin{array}{l}2,3, \mathrm{R} \text { 階梁断面 } \\
\text { 柱断面 } \\
\text { ヤング保数 } \\
\text { せん断弾性係数 }\end{array}$ & $\begin{array}{l}: 40 \mathrm{~cm} \times 80 \mathrm{~cm} \\
: 60 \mathrm{~cm} \times 60 \mathrm{~cm} \\
: 2.1 \times 10^{5} \mathrm{~kg} / \mathrm{cm}^{2} \\
: 0.9 \times 10^{5} \mathrm{~kg} / \mathrm{cm}^{2}\end{array}$ \\
\hline 基 & $\begin{array}{l}\text { 基礶梁断面 } \\
\text { 基整スラブ厚 } \\
\text { ヤング保数 } \\
\text { せん断弾性保数 }\end{array}$ & $\begin{array}{l}: 40 \mathrm{~cm} \times 120 \mathrm{~cm} \\
: 40 \mathrm{~cm} \\
: 2.1 \times 10^{5} \mathrm{~kg} / \mathrm{cm}^{2} \\
: 0.9 \times 10^{5} \mathrm{~kg} / \mathrm{cm}^{2}\end{array}$ \\
\hline 硭 & $\begin{array}{l}\text { 杭径 } \\
\text { 肉厚 } \\
\text { ヤング保数 } \\
\text { せん断弾性係数 }\end{array}$ & $\begin{array}{l}: 40 \mathrm{~cm} \\
: 6.5 \mathrm{~cm} \\
: 4.2 \times 10^{5} \mathrm{~kg} / \mathrm{cm}^{2} \\
: 1.8 \times 10^{5} \mathrm{~kg} / \mathrm{cm}^{2}\end{array}$ \\
\hline 盤 & 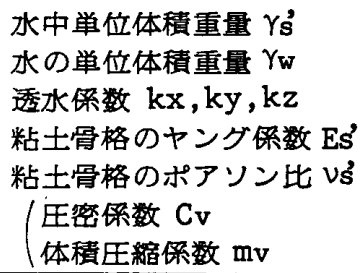 & $\begin{array}{l}: 0.7 \times 10^{-3} \mathrm{~kg} / \mathrm{cm}^{3} \\
: 1.0 \times 10^{-3} \mathrm{~kg} / \mathrm{cm}^{3} \\
: 0.12 \mathrm{~cm} / \mathrm{day} \\
: 11.11 \mathrm{~kg} / \mathrm{cm}^{2} \\
: 1 / 3 \\
: 2 \times 10^{3} \mathrm{~cm}^{2} / \mathrm{day} \\
\left.: 6 \times 10^{-2} \mathrm{~cm}^{2} / \mathrm{kg}\right)\end{array}$ \\
\hline
\end{tabular}

お，別途検討した結果 ${ }^{21)}$ ，压密全過程を問題にする場合 には，鉛直方向分割については分割数が同じであれば等 分割とした方が好ましい結果が得られたので，本報では できるだけそれに準じるようにした。

解析結果として, 表一 6 に建物中央部の絶対沈下量 $w_{A}$, 建物辺部の絶対沈下量 $w_{c}$ および両者の相対沈下量 $\delta_{A C}$ を示した。まず, 鈶直方向分割数のみ異にする RS-1, $\mathrm{E} ， 2$ および RP-1，E，2 についてみると，建物に生ず 
る絶対沈下量は，両系列共分割数が多くなるにつれて増 大する。相対沈下量は，RS 系列では分割数が多くなる につれて減少するのに対して，RP 系列では逆に増加す る傾向を示す。しかし, 各モデルの絶対沈下量および相 対沈下量とそれぞれ対応する基本モデルのそれとの差は 極めて小さい。また，水平方向分割数の影響についても， 鉛直方向分割数の場合と同様の傾向がみられ，本解析モ デルの範囲では分割数の違いによる沈下分布の差は小さ いと云える。さらに，先に示した図一4 が見掛けのすべ り量を基にして定められたことも考慮すると水平方向分 割数をあまり細かくすることは本報のモデルの設定条件 から逸脱することになる。

図一9は柱・はりの応力分布を比較したものである。 図には基本モデルおよびそれと最も応力分布を異にする モデルについて示した。それによると，RS-Eでは上部 構造の荷重がすべて柱下から地中へ伝達されるのに対し て，RS-3では基礎ばりや基礎スラブからも伝達される ために，両者の基礎ばり曲げモーメントがそれぞれ異 なった分布を示す。これに対して，RS 系列の基礎ばり 以外の部材および RP 系列の全部材では両者の応力分 布が近似しており, 基本モデル程度の分割でも全体の応 力性状をおおむね表し得るものと思われる。

また，別途検討した結果 ${ }^{21)}$, 圧密方程式を差分近似す る場合には, 解が安定する範囲でできるだけ時間刻みを 大きくすることが精度を損ねることなく効率的であっ た。その結果に基づいて定めた本報の時間刻み $\Delta t$ は, 基本モデルで $\Delta t=1$ 日, $\mathrm{H} 2$ 分割とした $\mathrm{RS}-3$ および RP-3 で $\Delta t=0.1$ 日となって, 分割数の増加とともに 大幅に小さくする必要がある。さらに, RS-3および RP-3 では剛性マトリックスの元数も增えるため, 同じ 圧密過程の計算に要する計算機の演算時間は基本モデル の約 20 倍にもなり，極めて不経済である。

以上の諸点から, 本報の基本モデル程度の分割方式を 用いても, 実用的には十分な精度で沈下過程の解析を行 い得るものと考え, 以降の解析においてはその方式に準 じることにする。

\section{3 非排水変形分布について}

表一6によると，建物の即時沈下量は終局時までの全 沈下量のほぼ $1 / 2$ を占めており,このような地盤におい ては粘性土の非排水せん断変形が極めて重要なファク ターとなる。

非排水変形を得るための方法として，地盤のポアソン 比レを 0.5 に近づけて間隙水圧を考虑しないで弾性解 析する方法（ここでは以下 $\nu$ 法と記す）がこれまでし ばしば行われてきた。そこで， ルを有限要素法解析して得た値と, 有効応力に基づいた 本解析法による非排水時の値を比較することにする。 地表面沈下分布を示した図一10によると，建物中央
表-4 水平方向分割方式 (単位：m)
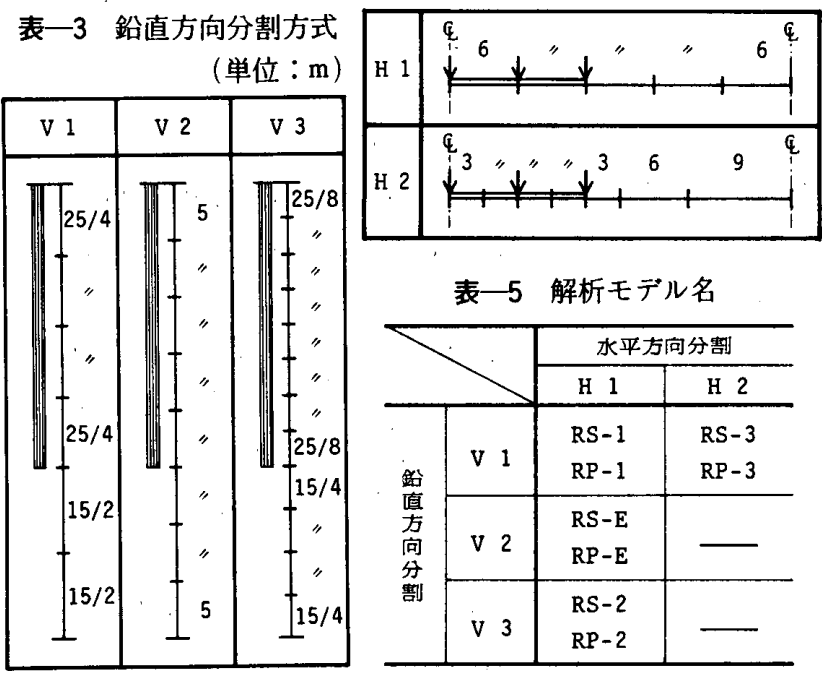

表一6 建物の絶対沈下および相対沈下 (単位：m) ※RP-E の（）内は杭の曲げ剛性を考虑した場合

\begin{tabular}{|c|c|c|c|c|c|c|c|}
\hline & \multicolumn{2}{|c|}{ WA } & \multicolumn{2}{|c|}{ WC } & \multicolumn{2}{|c|}{$\delta_{\mathrm{AC}}$} \\
\hline & & 即時 & 釉局時 & 即時 & 释局時 & 即時 & 終局時 \\
\hline \multirow{4}{*}{$\begin{array}{l}\text { RS } \\
\text { 系 } \\
\text { 列 }\end{array}$} & RS-1 & 24.2 & 49.3 & 22.4 & 47.5 & 1.81 & 1.87 \\
\hline & RS-E & 24.6 & 49.7 & 22.8 & 47.8 & 1.79 & 1.85 \\
\hline & RS-2 & 24.9 & 50.2 & 23.2 & 48.3 & 1.76 & 1.82 \\
\hline & RS -3 & 25.0 & 50.9 & 23.4 & 49.3 & 1.62 & 1.64 \\
\hline \multirow{4}{*}{$\begin{array}{l}\mathrm{RP} \\
\text { 系 } \\
\text { 列 }\end{array}$} & $\mathrm{RP}-1$ & 11.4 & 22.6 & 9.8 & 20.9 & 1.64 & 1.64 \\
\hline & $R P-E$ & $\begin{array}{l}11.8 \\
(11.7)\end{array}$ & $\begin{array}{c}22.9 \\
(22.8)\end{array}$ & $\left(\begin{array}{l}10.1 \\
(10.1)\end{array}\right)$ & $\begin{array}{r}21.3 \\
(21.2)\end{array}$ & $\begin{array}{l}1.67 \\
(1.63)\end{array}$ & $\begin{array}{l}1.65 \\
(1.58)\end{array}$ \\
\hline & $\mathrm{RP}-2$ & 12.0 & 23.2 & 10.3 & 21.5 & 1.70 & 1.68 \\
\hline & $\mathrm{RP}-3$ & 13.1 & 24.4 & 11.3 & 22.6 & 1.73 & 1.73 \\
\hline
\end{tabular}
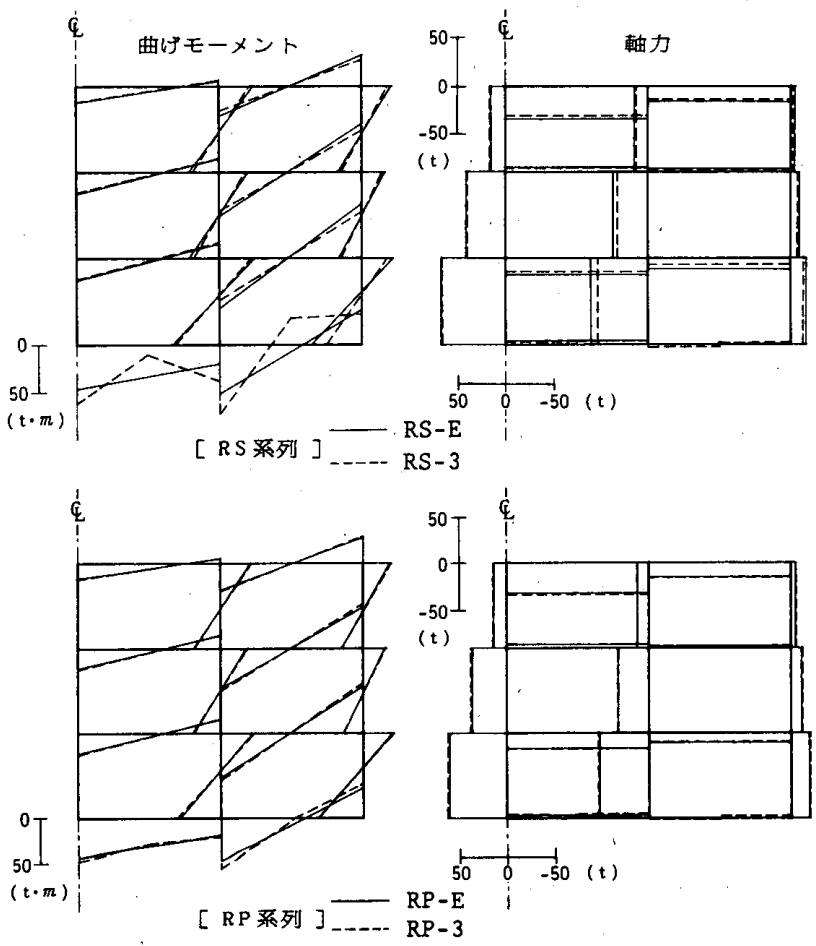

图一9 柱・はりの応力分布 ( $Y_{0}$ 断面, 終局時) 


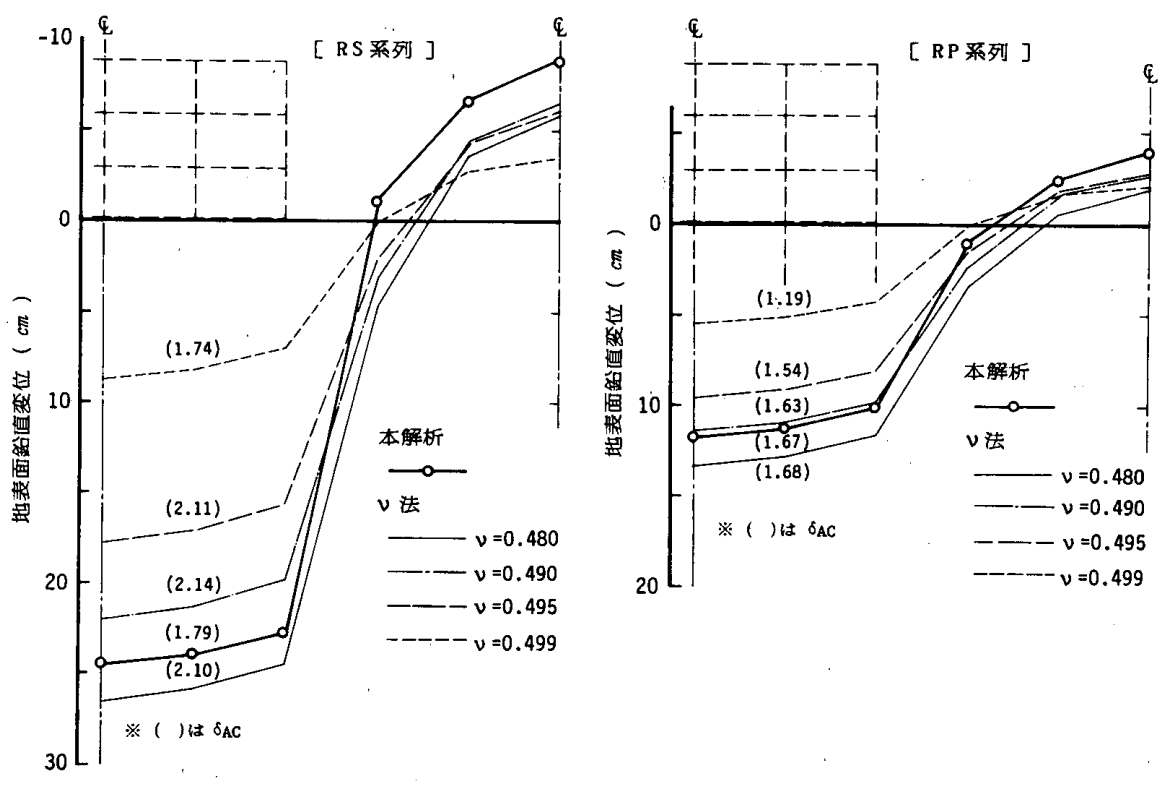

図一10 地表面沈下分布 ( $Y_{0}$ 断面, 即時)

部と辺部の相対视下 $\delta_{A C}$ は, RS 系列および RP 系列に ついてポアンン比をそれぞれ 0.499 および 0.480 にした 時の $\nu$ 法の值が, 本解析法の值に比較的近似していた。 しかし， $\nu$ 法では地盤の体積変化が生ずるため, 本解析 法の分布に比べて周辺地盤の盛り上り量がいずれも小さ くなっている。また, 体積変化を生じさせないためには, できるだけポアンン比を 0.5 に近づければ良いが，（4) 式の分母が 0 に近づいて地盤の弾性剛性が見掛け上極め て増大することになって, 建物沈下量が極めて小さく計 算される。以上の事から, 解析モデルに応じて適切なポ アソン比を選定できるならば, $\nu$ 法によって建物の相対 沈下を推定できることになる。しかし，建物の絶対沈下 や周辺地盤の変形分布については大きな誤差を含むこと になるので, より精度の高い非排水変形を求める必要が ある場合には有効応力概念に基づいた本解析法によるべ きであると考える。

\section{4 圧密沈下過程について}

初期過剩間隙水圧分布を示した図一11によると, RS-E では建物直下に過剩間隙水圧 $P_{w}$ が集中するのに 対して, RP-Eでは杭に囲まれた領域の $P_{w}$ は極めて小 さく杭先端部に集中している。また，周辺地盤の $P_{w}$ は, 建物から水平方向および鉛直方向に遠ざかるにつれてそ れぞれ減少および増加している。これらの $P_{w}$ が消散す ることに伴う圧密沈下の進行過程を示したのが図一12 である。なお，図中には初期過剩間隙水圧が深さ方向に 線型分布であると仮定して求めた Terzaghi の一次元圧 密曲線も示してある。それによると，周辺地盤部@では 初期における圧密の進行が遅いのに対して, 建物中央部 (A)ではこれよりもかなり早くなることが分った。これは 初期過剩間隙水圧が深さ方向に複雑な非線型分布となる ことによる影響と，建物下部および杭先端部の $P_{w}$ が,

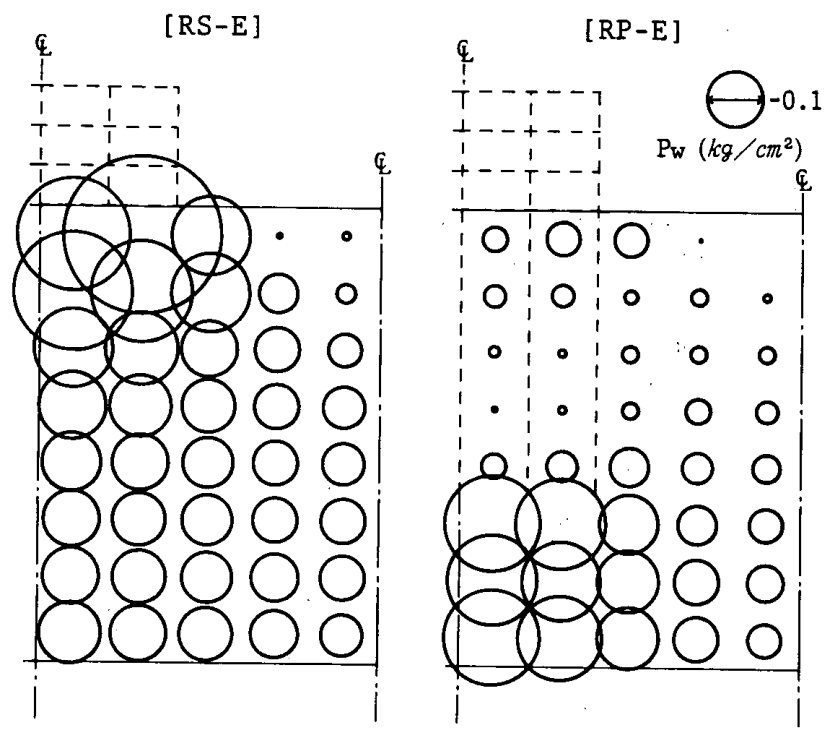

图一11初期過剩間隙水圧 $\left(Y_{0} \sim Y_{1}\right.$ 間要素)

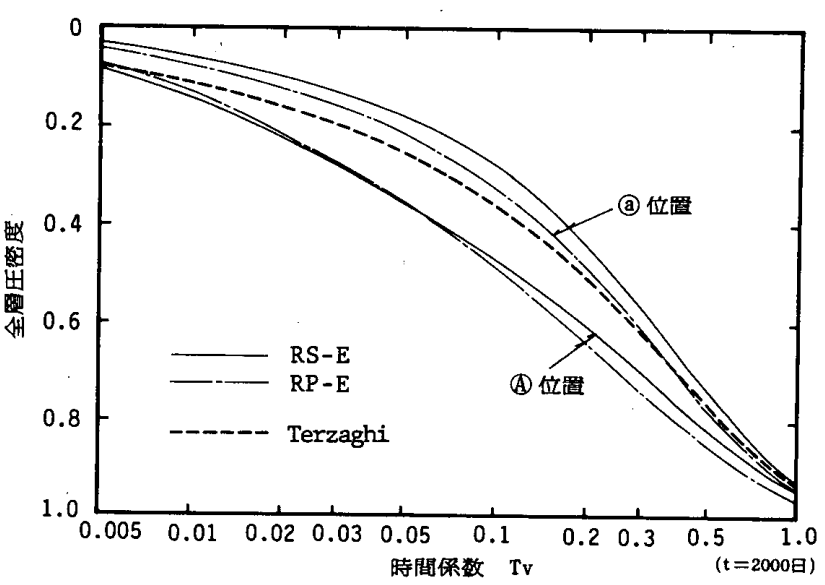

図一12 全層圧密度の経時変化

より $P_{w}$ の低い周辺地盤へ水平方向に消散することの影 響によるものと考えられる。以上のように，圧密による 
建物の沈下過程は Terzaghi の一次元圧密曲線とはかな り異なることが分った。

\section{§4. まとめ}

以上, 粘性土地盤における建築構造物の沈下過程解析 法を提示するとともに，予備計算を行って本計算を進め るにあたっての検討を行ってきた。その結果をとりまと めると以下のようになる。

(1) 本報で導いた三次元の粘土要素は, 地盤の非排水 せん断変形と圧密変形の両者を良く表現できると考えら れるので，粘性土が地表面から続くような軟弱地盤の解 析に適用することができる。

(2) 基礎ばり，基礎スラブおよび杭の要素と地盤の要 素との要素節点間における非適合条件は, 解析結果にあ まり影響を与えない。

(3) 図一 8 に準じた分割方式を用いた有限要素法解析 によって，建築構造物の沈下過程をおおむね知ることが できる。

本報の解析方法に基づいた計算結果については次報で 論ずる予定である。

\section{参考文献}

1）横尾義貫・山肩邦男：地下粘土層の圧密による構造物の 不同沈下について, 日本建築学会論文集 50 号, pp. 88 94, 1955.3

2）大崎順彦：不同沈下による上部構造応力の理論解および 実用近似解法, 建築研究所研究報告, No. 18, pp. 1 10, 1956.3

3）松浦 誠：構造物の剛性を考虑した不同沈下の実用算定 法, 日本建築学会論文報告集 66 号,pp. $617 \sim 620,1960$. 10

4）中田啓一・山肩邦男：くい基礎を持った建築構造物の沈 下に関する理論的研究 (第 1 報), 日本建築学会論文報告 集 274 号, pp. 55 64，1978.12, 以下一連の論文

5）松浦 誠・山本春行：軟弱地盤上のベ夕基礎を有する構 造物の不同沈下に関する解析的研究，日本建築学会論文 報告集 331 号, pp. 18 26, 1983.9

6）赤井浩一・小沢良夫：基礎バリの剛性を考虑した接地王 と沈下について, 第 3 回土質工学研究発表会, pp. 135 140,1968

7) P. Brown : Structure-Foundation Interaction and Soil Creep, Proc. of 9th Int. Conf. on Soil Mech. and Found. Eng., Tokyo, pp. 439 442, 1977
8) S. Chamecki : Soil-Structure Interaction in the Analysis of Raft Foundations, Arch. Inz. Ladowej 25-4, pp. 559 $\sim 572,1979$

9) S. Chamecki : Structural Rigidity in Calculating Settlements,. Proc. of A.S.C.E., Soil Mech. and Found. Div., pp. 1 19, 1956.1

10）芳賀保夫：不同沈下におよぼす建物の剛性等の影響につ いて (第 2 報)，日本建築学会論文報告集 206 号, pp. 1 $-8,1973.4$

11）須藤福三・和田 章：横に長い圧密沈下構造物の 2 次元 有限要素法による構造・地盤の一体解析, 日本鋼構造協 会, 第 5 回大会マトリックス構造解析法研究発表論文集, pp. 394 401, 1971.6

12) S.J. Hain and I. K. Lee : Rational Analysis of Raft Foundation, Proc. of A.S.C.E., Geotech. Eng. Div., pp. $843 \sim 860,1974.10$

13) R.A. Fraser and L. J. Wardle : Numerical Analysis of Rectangular Rafts on Layered Foundations, Geotechnique $26-4$, pp. $613 \sim 630,1976$

14) M. Kany : Methods of Analysis for Structures on Settling Ground, Proc. of 9th Int. Conf. on Soil Mech. and Found. Eng., Tokyo, pp. 581 585, 1977

15) J. T. Christian: Undrained Stress Distribution by Numerical Methods, Proc. of A. S. C. E., Soil Mech. and Found. Div., pp.1333 1345, 1968.11

16）最上武雄・ほか：土木学会監修 土質力学, 技報堂, 1969

17）赤井浩一・田村 武：多次元圧密問題に対する非線型応 力一ひすみ理論の適用, 京大防災研究所年報第 19 号 $\mathrm{B}$, pp. $1 \sim 15,1976$

18）井上嘉信 -小林幸男・玉置克之：杭に㗢く負の摩擦力の 性状に関する考察, 清水建設研究所報 24 号, pp. 21 35, 1975

19）土質工学会編：土質基磷工学ライブラリー 1 軟弱地盤 の調査・設計・施工法, 土質工学会, 1966

20）玉置克之・土屋 勉：施工時の建物の沈下実測結果およ び沈下推定に対する現位置式験結果の適用性の検討，清 水建設研究所報 35 号, pp. 1 9, 1982

21）土屋 勉・内田哲也・大築和夫：有限要素法による飽和 粘土地盤の三次元圧密解析, 日本建築学会北海道支部研 究報告集, No. 57, pp. $217 \sim 220,1984$

22）土屋 勉-内田哲也・大築和夫 -小幡 守：有限要素法 による粘性土地盤に載る建築構造物の沈下過程解析 そ の 1 その 2, 日本建築学会大会学術講演梗概集, pp. 2469 2472, 1984 


\section{SYNOPSIS}

UDC : 624. $131.55: 624.131 .542$

\section{THREE-DIMENSIONAL FINITE ELEMENT ANALYSIS OF THE SHEAR SETTLEMENTS AND THE CONSOLIDATION SETTLEMENTS OF FRAME STRUCTURES ON POOR GROUNDS}

by TSUTOMU TSUCHIYA, Lecturer of Muroran Institute of Technology, Dr. KAZUO OHTSUKI, Professor of Muroran Institute of Technology and Dr. MAMORU OBATA, Professor of Hokkaido University, Members of A. I. J.

The purpose of this paper is to investigate the differential settlements of frame structures on cohesive soils which are layered from ground surface to considerably deep stratum.

In this paper, a three-dimensional finite element method has been presented to analyze the structurefoundation-soils interaction. The following idealizations have been made in the method :

1) The three-dimensional element which has been derived from the effective stress principle so as to represent the shear settlements and the consolidation settlements is used for the soils.

2) The linear elastic beam element is used for the superstructures and the foundations.

3) The elasto-plastic linkage element which has been expressed as a function of effective overburden pressure and slip along the pile shaft is used for the joints between piles and soils.

And further, the preliminary analysis for the non-conforming condition between the element of foundations and that of soils as well as the analysis for the size of finite element mesh have been executed. As a result, we conclude that the present method is suitable to analyze the settlement process of both frame structures with spread foundations and those with friction pile foundations on poor grounds. 